\title{
A Neglected Irish Novelist: Marmion W. Savage
}

The Leigh Hunt Collection in the Special Collections Department of The University of Iowa Libraries contains one of only three known letters written by Marmion Wilme Savage (1803-1872), an almost-forgotten Irish writer who was known in mid-Victorian literary circles as the author of lightly satiric fiction. ${ }^{1}$ This important letter, telling about and suggesting by way of implication the interesting matters which surround the life and writings of Savage, is dated July 25, 1870, and is addressed to William Bayle Bernard, who at the time was writing his biography of the Irish poet and novelist Samuel Lover. Bernard had asked Savage for his literary correspondence with Lover to include in the biography. Savage replies to Bernard that he had received only two short notes from Lover during his lifetime and that they are not immediately available:

Dear Sir,

\author{
Enfield Villa \\ Torquay \\ July $25[1870]$
}

Between years and ill health I am slow in my movements and I beg you will not attribute to any indifference on the subject of your letter my tardiness in answering it. On the contrary it would be a great pleasure to me to be able to make any contribution towards the memory you propose of a friend whom I valued and regretted as much as Samuel Lover.

1 Although Savage lived in England for the last 16 of his 69 years. his birth, upbringing, education, and long residence in Dublin, coupled with the Irish settings of two of his novels and his concern for Irish affairs in other of his writings seem to call for defining him as an Irish author. For further discussion of this problem of Irish/English definition see Thomas Flanagan. The Irish Novelists: 1800-1850 (New York: Columbia University Press. 1959), pp. 35-50. 
It would also, I hope you will assure his widow, be a great pleasure to me to gratify her in any way. But in fact between two men who were united by the ties of friendship there never was less literary correspondence than there was [between] Lover and myself. I do not think I had ever more than two short notes from him for they could hardly be called letters. One of those I should certainly be glad to lend you, if I could lay my hands on it, for I think there were some verses in it, and I know, whether in prose or verse, it was pleasant and characteristic. I have directed a search to be made for it among my papers in London. If I recover it I shall not fail to send it to you.

Bernard probably never received the short note, since it is not mentioned as a source in his Life of Samuel Lover, published in 1874.

Savage's letter to Bernard describes his friendship not only with Samuel Lover but also with Albany Fonblanque, editor of Leigh Hunt's Examiner in London between 1830 and 1847. Savage had followed Hunt, Fonblanque, and John Forster as fourth editor of the prestigious Examiner. As Savage tells us in this letter of 1870, he met Albany Fonblanque early in the summer of 1835. Fonblanque had thereafter invited Savage to his yacht for a trip to the mouth of the Thames, and it was during this voyage that Savage first met Samuel Lover.

Not only was I unfortunate in having so little epistolary commerce with the subject of your proposed biography, but our personal meetings since I knew him in 1835 were few and far between. Our acquaintance commenced at sea, on board the yacht of our common friend Albany Fonblanque, on a cruise about the mouth of the Thames. I had made Fonblanque's acquaintance the same summer, of which I therefore cherish the memory with gratitude for adding two such names to the host of friendships which I have had the happiness to enjoy in my time. By the bye, neither Lover nor I had any vocation to either business or pleasure in the mighty deep. The weather was rough, but not very bad I believe, at least I remember the experienced yachtsman showing so little respect to the ill-concealed apprehensions of his friends as even to treat them with ridicule, in fact he laughed at us in the sleeve of his seaman's jacket, or I believe his pilot-coat.

The letter sheds considerable light on all three periods in Savage's own life. ${ }^{2}$ The first period (1803-1844), referred to above, includes Savage's youth and graduation from Trinity College, Dublin, as well

2 The destructions in Dublin during 1922 obliterated many of the family and professional records of Savage and his father, The Rev. Henry Savage, as well as the birth and marriage certificates of Olivia Clarke Savage and Narissa Rosavo Savage, and the birth certificate of Henry Arthur Savage. 
as his appointment as first clerk to council at Dublin Castle. This was a responsible position which he held until 1856, when he moved to London. During this time, in 1839, he and Edward Berwick published "Commission on Irish Railways," an essay deriving from his interests in the Castle. ${ }^{3}$ A letter (now in the British Library) from Savage to Macvey Napier, telling about the delay in sending this article, has biographical interest only in that it gives Savage's 1839 address as 24 Mecklenburgh Street.

Although Mecklenburgh Street is now an industrial area in Dublin, the Marmion Savage home would have been an entertaining and a gracious one in 1839 when Savage was 36. The author had a lifelong reputation for excellent conversation, and Lionel Stevenson in his The Wild Irish Girl tells us that Savage's first wife, Olivia Clarke Savage, was known for her lovely appearance as well as for her pleasing talents for extemporaneous French charades and Italian singing. Olivia's parents, Sir Arthur and Lady Clarke, and her maternal aunt, Lady Morgan, added not a little glitter to the family circle. Lady Clarke had a reputation for witty conversation and Lady Morgan was a well-known Irish novelist. Sir Arthur Clarke and Sir T. C. Morgan were physicians of note. ${ }^{4}$ Marmion and Olivia had one son, Henry Arthur Savage, who was born about this time.

During this first period in Savage's life, he also established himself in a literary circle. On May 19,1838, he is recorded as having dinner at Fonblanque's in London. Other guests of Fonblanque included William Charles Macready, John Forster, Saw Hayward, F. Reynolds, Dr. Quin, Count D'Orsay, Walter Savage Landor, Bulwer, and Lord Nugent. ${ }^{5}$ Macready was a famous actor and Forster was Fonblanque's literary editor at the time. The names of Savage's earliest journalistic associates are preserved in Albany Fonblanque's autobiography. Well-known people who contributed articles to the Examiner between 1830 and 1847, which Fonblanque calls its "palmiest" days, included Marmion Savage, Thackeray, John Stuart Mill, Charles Dickens, and Walter Savage Landor. ${ }^{6}$ Savage, then, was known in Ireland and England before he began publishing his novels.

3 [Marmion Wilme Savage and Edward Berwick] "Commission on Irish Railways," Edinburgh Review, 69 (April 1839), 156-88.

4 Lionel Stevenson, The Wild Irish Girl: The Life of Sydney Owenson, Lady Morgan (1776-1859) (London: Chapman \& Hall. 1936), pp. 141-46.

5 William C. Macready. The Diaries of William Charles Macready 1833-1851, ed. William Toynbee (New York: G. P. Putnam's Sons, 1912), I, 457.

6 Albany Fonblanque, The Life and Labours of Albany Fonblanque, ed. by his nephew Edward Barrington de Fonblanque (London: Richard Bentley \& Son, 1874 ), p. 37. 
It was during a second period in Savage's life (1845-1855), the decade following the death of his first wife, that most of his novels were published. Unfortunately, we have little biographical information concerning this important phase, but Savage helps us understand it more fully when he writes to Bernard:

From that period for nearly twenty years it was my fate never once, to my remembrance, to have met Lover again afloat or ashore. This was owing to my residence during the greater part of that interval in Ireland.

This comment, evidence of Savage's continuing residence in Ireland through the major part of his novel-writing period, suggests a biographical irony: although Lover (1797-1868) is now pointed up in our Victorian literary histories as an outstanding Irish poet, he was actually living in England after 1835, while Savage, a talented native resident of Dublin for the first 53 of the 69 years of his life, has been largely ignored by Irish scholars.

Savage and Lover met again in London during Savage's third period (1856-72) while Savage was editor of the Examiner and while his son was a member of the London Irish Corps.

We met again however on my removing to London, and the renewal of our friendly relations was connected with the Volunteer movement in a way that has left a deep impression on my memory of the kindness which was as much part of Lover's nature as the humour and wit which delighted the world. Suffice it to say that my son (whom I lost a year or two later) joined the London Irish Corps in which Lover was an officer, and was greatly indebted to him for his advice and friendship on several occasions when a lad under twenty would otherwise have been at a loss for guidance. Excuse this garrulity which I would not trouble you with if I had anything of value to give you in its place. I have only to add that I take a lively interest in the work you have undertaken and heartily wish it success.

Yours truly dear Sir Marmion Savage

Savage's son, Henry Arthur Savage, is mentioned by several of his father's obituary writers as dying "in early youth." This letter is more specific and says that Henry Arthur was under 20 "a year or two" before he died. Clearly, Savage appears to admire Lover as well as his fellow editor, Fonblanque, and his concern for Bernard becomes evident when we note his postscript:

PS. Please excuse this pencil, my only way of writing, as I can only write in a recumbent posture. 
Surely it would have been easier, in 1870 , for Savage to ignore a biographer's query. Savage was suffering from cardiac disease which, when complicated by bronchitis, caused his death two years after writing this letter.

Apparently before 1856, when he left Ireland, Savage married for a second time. His wife, Narissa Rosavo Savage, called Rosa, was the daughter of Thomas Hutton of Dublin. ${ }^{7}$ Rosa survived Marmion. The two had no children.

This letter leads to the end of a life of a writer who has been generally unrecognized. Savage's novels have skillful light satire which adds a dimension to what we think of as the Victorian novel. They contain a balanced scrutiny of Irish problems which can extend our knowledge of his times.

Savage's position as clerk to council at Dublin Castle during the early agitations for repeal of the union with England made it wise for him to elect to remain anonymous to the general reader. In addition, he had a distaste for personal fame, though his novels were popular and usually suggest moderate political views which were supported by the mid-nineteenth-century Whig supremacy. When Savage finally released his name in 1852 , his major fiction had been written and the Whigs had little more than a decade of influence left. Contemporary reviews of his books were usually more political than literary.

Then, unfortunately, the political excesses and antagonisms Savage had happened to observe grew to an unprecedented importance in the minds of readers so that his lightly satiric art became secondary to his minor topical interests. Finally, later Irish writers became so nationalistic that they had little interest in the views of a moderate man delineating the conditions of political union with England. For these reasons his novels attracted little attention from subsequent literary critics.

Savage used light satire in all five of his long novels. ${ }^{8}$ His satire implies as a norm the humane attitudes fostered by well-educated Irishmen and Englishmen who clung to a belief in moderation. These golden-mean values were inherited from Alexander Pope, Samuel Johnson, and other great thinkers from the eighteenth-century enlightenment.

7 Dictionary of National Biography, s. v. "Savage, Marmion W."

8 For a definition and full discussion of Savage's light satire, see Paralee F. Norman, "A Study of Light Satire in Three Novels Written by Marmion Wilme Savage," Ph.D. Diss., The University of Iowa, 1978, pp. $20 \mathrm{ff}$. 
Savage's first novel, The Falcon Family; or, Young Ireland, was published anonymously in 1845 by Chapman \& Hall and became popular. It satirizes social parasites, the extreme militants for Irish independence, and the enthusiasts for medieval revival in the English church. The Falcon Family was dedicated to Olivia's aunt, Lady Morgan. In a preface to the second edition of 1846, written from Stolzenfels on the Rhine, Savage says he appreciates the novel's rapid success and takes note of current affairs which now support the book's satiric attitude toward the extremes of "Young Ireland."

Appearing just two years after The Falcon Family was Savage's second novel, The Bachelor of the Albany (1848). It satirizes those who lead narrow lives for themselves alone, while telling the story of a Mr. Barker who develops a wider interest in people. At the same time it makes fun of excesses in the Irish and English churches. Equally rapid was the publication of his next novel, My Uncle the Curate (1849). Set in the Irish countryside, this novel combines a fully developed adventure plot with detailed satires of characters and customs as well as of a self-indulgence which permits social problems to continue.

Three years later, during this decade of outstanding creative productivity, his fourth long fiction was published. This was an extremely popular book called Reuben Medlicott; or the Coming Man (1852) which had a variant title for the edition of 1860, The Universal Genius; or, the Coming Man. This novel is a satiric spoof of Reuben Medlicott's lifelong sensibility and complacency. Reuben's years from school to an adult career in oratory and then to an unexceptional widower's retirement are given full and witty attention in the novel. The satirist holds up to ridicule Reuben's unlucky and naive abandonment of various careers and asks us to laugh at, rather than indulge in, such unstable behavior.

Savage's final novel, The Woman of Business; or, the Lady and the Lawyer, appeared as a serial in 1869-70 and was published in book form in London and New York in 1870. While also satirical, this book is written in a naturalistic mode, yet it expresses an optimistic Darwinism. Savage asserts that despite the operation of inevitable natural forces there are obvious developments of the human spirit. He gives his readers full analyses of the operation of heredity and environment within and upon major characters. His light satire here is usually concentrated in incidental expression of character.

Six or more editions of the first four of these novels were published, all appearing in Mudie's Select Library and in Ward \& Lock's 


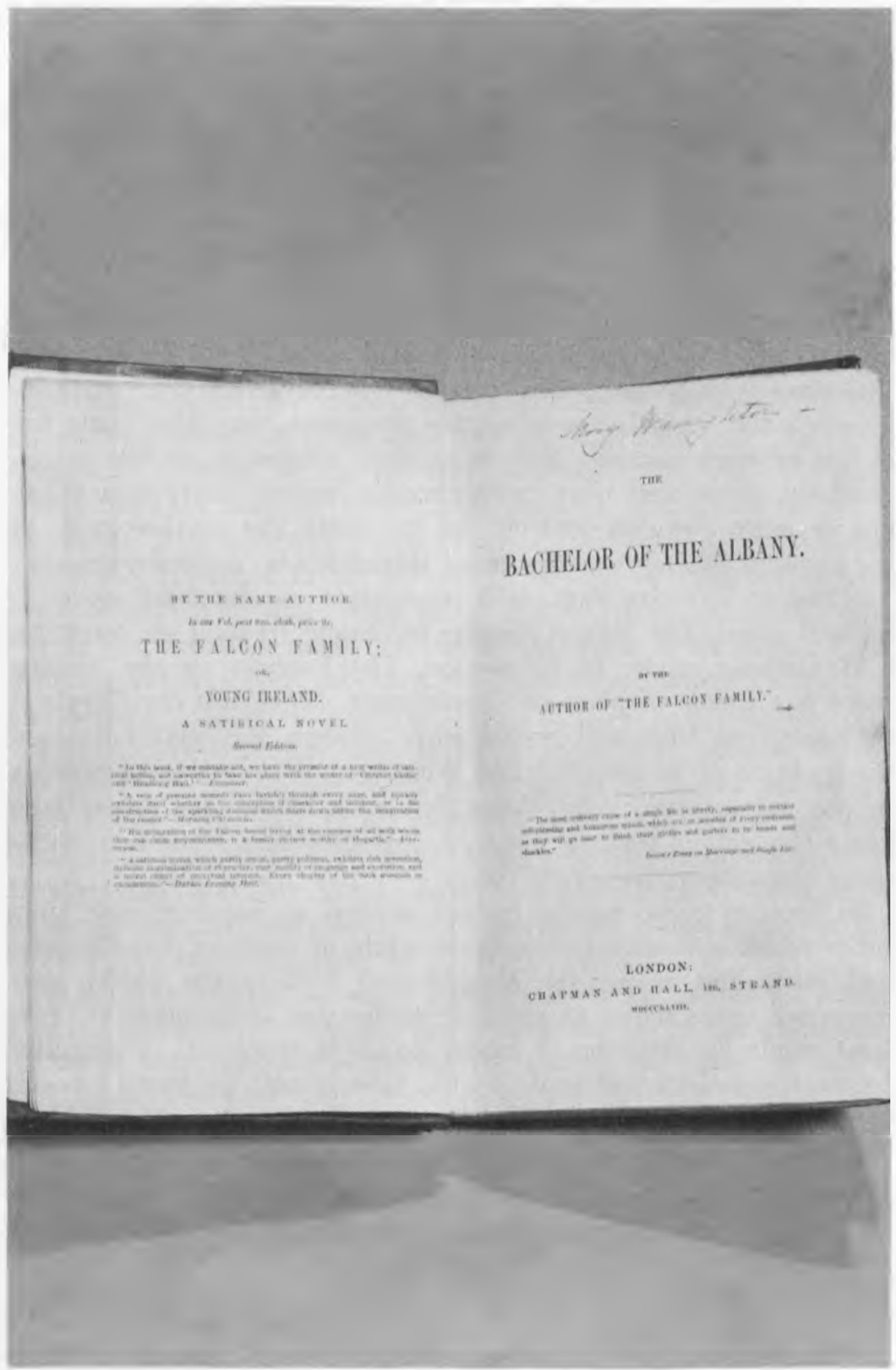

Marmion W. Savage's second novel was The Bachelor of the Albany (London 1848), shown above in a copy of the first edition owned by The University of Iowa Libraries. 
Select Library of Fiction. ${ }^{9}$ The most recent edition of a Savage novel is the 1927 Rescue Series publication of The Bachelor of the Albany, which was introduced by Bonamy Dobrée. Dobrée describes the effect that Savage's novels have on readers:

... We feel that we are in the presence of a man of culture and kindliness, not wanting in power or deftness, but sceptical of reforming human nature, though hopeful of cultivating the mind.10

Given an opportunity, readers of Savage can appreciate him as the master of a specialized and difficult type of Victorian novel. Victorians usually wrote their novels in mixed kinds. For example, although the novels were essentially romances, they also made use of one or more elements such as mystery, adventure, or the gothic. Similarly, pieces that were predominantly realistic might also utilize one or more elements such as the historical, the psychological, or the scientific. Savage's novels are of, several kinds (multi-subgeneric), but, true to Victorian form, each emphasizes one dominant mode. In his first novel, The Falcon Family; or, Young Ireland, we recognize a Hogarthean mode. In his second, The Bachelor of the Albany, there is a theme of personal development. My Uncle the Curate is set against an Irish background while Reuben Medlicott follows in the tradition of "sensibility." The Woman of Business is recognizably in the naturalistic mode. These dominant modes are mixed with lesser elements of realism, romance, and adventure while light satire plays throughout the novels.

In his first three novels, Savage created an amusing and quiet satire which encourages an understanding of many of the pleasures and difficulties among the English and Irish in the 1840s. Here corrective satire shows us zones of moderation as solutions to problems, while his selection of modes points to the kinds of problems his contemporaries had to deal with. Savage used his various modes to support an admiration of the Irish people as well as the English, and his satire encouraged a moderate domestic and political arbitration.

9 Sara Keith, Mudie's Select Library: Principal Works of Fiction in Circulation in 1848, 1858, 1869: Catalogues Arranged and Indexed (Ann Arbor, Michigan: n.pub., 1955), p. 156.

10 [Marmion Wilme Savage] The Bachelor of the Albany, Rescue Series, intro. Bonamy Dobrée (London: Elkin Mathews \& Marrot, 1927), p. 14. 
In addition to novels, Savage wrote or edited a variety of literary works. His first known publication, "The Gnostics," appeared with illustrations in the 1832 Amulet. It is a detailed discussion of the history of the gnostic sects. Savage may have made poetry the vehicle for his earliest experiments with light satire. In 1844, at the age of 41 , he published a mildly satiric poem about excesses in fashion called "The Song of May Fashions." Appearing in the May 4 Athenaeum and signed simply "M.W.S.," it is only one of his many known poems, the remainder of which appear in his five novels. As an editor, Savage is known to have conducted the Annual Register for many years, ${ }^{11}$ to have served as one of the most able writers for the Examiner, and to have written an introduction to his own collected edition of the writings of an Irish barrister which he called Sketches Legal and Political by the Rt. Hon. Richard Lalor Shiel. He published the Irish railways article with Berwick and wrote an examination of Irish progress called "Lord Clarendon's Administration" which was published in the Edinburgh Review of 1851. The article draws attention to some Irish social and economic advances made during the wracking potato famines of the 1840s. If we consider the enormity of those Irish problems, we realize that Savage enumerates and discusses the reforms tactfully.

Extremes in opinions and behavior were still condemned by Savage in the mid-1850s when he wrote three pieces of related short fiction. "Narrative of an Excursion to the Limbos, in Spiritual Company," and its two sequels, "A Second Flight; or, A Visit to Hobby-Land" and "My Third Flight; or a Visit to the Great Anthropophagus and his Dominions," were published anonymously in the Dublin University Magazine in 1853 and 1854.

As in his novels, the objects of his satire in shorter pieces fall within a broad spectrum. On the one hand, he is critical of the ephemeral nature of historical reform movements, and on the other, he uses a mild comedy to point out humanity's simple, personal crotchets. He calls these latter "hobbies" in the manner of Laurence Sterne's Tristram Shandy. A passage such as the following ridicules England's and Ireland's failures to complete reform measures in his time. The speaker in the text talks as if he were a resident of England:

11 David J. O'Donoghue, The Poets of Ireland: Biographical Dictionary with Bibliographical Particulars (London: Published by the Author. 1892-93), p. 222. 
. . Our dear country had furnished some curiosities too, particularly projects to pay off the national debt, plans of sanitary reform, schemes for national education, and a number of charming dreamy undertakings to reconcile the punishment of crime with the comforts and luxuries of criminals, and make prisons and penitentiaries as like snug, commodious and handsome country-houses as possible. We had also contributed two superb bubbles, long since burst and vanished into air, called Annual Parliaments and Universal Suffrage; to which there were recently added from Ireland another bracenamely, Tenant Right and Repeal of the Union.12

Savage believed in the essential rightness of these abortive attempts at reform, and he laments the fact that they failed. In so doing he calls our attention to the proverbial vanity of human wishes and indirectly to the ways in which people approach reform. Although these three short fictions have interesting classical and metaphysical allusions, they lack the drama and the immediate observations which in his novels are so well combined with concrete affairs.

Important to Savage's biography is his closet drama, "The Three Racans: An Anecdote Dramatized," which appeared in Fraser's Magazine for Town and Country in 1854. It discusses the reputation of writers and shows how popularity can get in the way of an artist's meaningful and productive living. Savage clearly believed in a full, active life unimpeded by excessive popularity. His attitude no doubt affected his own reputation adversely, inasmuch as he wrote anonymously for years. Also of biographical interest is a minor novelette called Clover Cottage; or, I Can't Get In (1856), which Savage may have written before he left Dublin for London. A signed presentation copy of this book given to his bachelor friend and colleague, John Forster, is now in the Forster Collection at the Victoria and Albert Museum Library in London. Forster married during 1856 at the age of 44. This story is about a bachelor who finally accepts a bride. It was later adapted as a one-act comedietta by Tom Taylor and renamed Nine Points of the Law. The first performance was given at the Royal Olympic Theatre on April 11, 1859. ${ }^{13}$

After several years of intense activity as editor of the Examiner, Savage retired to Torquay in County Devon for his health and waited six years, or until 1866, before publishing his last two nonfiction articles. These are very dissimilar. One reveals his religious convictions and the other is a lament over the top-heavy judicial system in

12 [Marmion Wilme Savage] "Narrative of an Excursion to the Limbos, in Spiritual Company," Dublin University Magazine, 42 (December 1853), 666-72. 13 Tom Taylor, Nine Points of the Law: An Original Comedietta in One Act (New York: Samuel French \& Son, 1860), p. [iv]. 
the Irish courts. "Religion and Philosophy Reconciled in Prayer," appearing in the Fortnightly Review of January 1, 1866, is a reminder to post-Darwinian intellectuals of the applicability and universality of simple Christianity. On March 1 of the same year, Fortnightly Review published his "Irish Judicial Establishment" which points to the inequities in Irish and English judicial establishments but, more importantly, to Savage's honesty in affairs. His emphasis is upon the idea that the Irish have too many judges for the amount of work that judges must do.

Savage had lived and worked in Dublin until he was 53, and he had acquired an almost limitless fund of native Irish lore to which he joined a remarkably broad classical scholarship and an uncommon ability as an administrator and editor. These qualities combined to create a Victorian of substance whom the Irish and English can both remember with pride. 